\title{
KNL1 Gene
}

National Cancer Institute

\section{Source}

National Cancer Institute. KNL1 Gene. NCI Thesaurus. Code C97378.

This gene is involved in both signaling and chromosome alignment in mitosis. 